\section{Selection of cotton genotypes for greater length of fibers}

\author{
Luiz Paulo de Carvalho ${ }^{1}$, Francisco José Correia Farias ${ }^{1}$, Camilo \\ de Lellis Morello ${ }^{1}$ and Paulo Eduardo Teodoro ${ }^{2 *}$
}

\begin{abstract}
In cotton breeding programs, it is necessary to identify genotypes with predictable behavior on the length of fibers, and which are responsive to environmental variations, in specific or broad conditions. The aim of this study was to employ the methodology of mixed models for simultaneous selection of cotton genotypes with greater length of fibers, adaptability and stability. It was evaluated 36 lines in three trials located in Apodi (2013 and 2014) and Santa Helena $(2013$,$) in a randomized block design with two replications. Genetic$ parameters were estimated by the restricted maximum likelihood/best linear unbiased predictor method (REML/BLUP) and the selection was based on the method of harmonic mean of the relative performance of genetic values. The genotypes CNPA 2012-55, CNPA 2012-58, CNPA 2012-62 and CNPA 2012-64 can be grown in all tested environments, since they gather greater length of fibers, stability and adaptability.
\end{abstract}

Key words: BLUP/REML, genetic parameters, Gossypium hirsutum L.r. Iatifolium Hutch.

\section{INTRODUCTION}

Upland cotton (Gossypium hirsutum L.r. latifolium Hutch.) produces one of the most important textile fiber of the world, and offers various utility products with great relevance in the Brazilian and the world's economy (Carvalho et al. 2015a, Menezes et al. 2015, Morello et al. 2015). However, changes in spinning technology, competition with synthetic fibers, and the globalization of cotton production and textile products increase the demand for higher quality fiber, making the length of fiber one of the main traits to be improved (Smith et al. 2008, Carvalho et al. 2016).

Genotype $x$ environment interaction ( $\mathrm{G} \times \mathrm{E}$ ) is one of the greatest challenges in plant breeding, both in the selection procedures and in the recommendation of cultivars, and plant breeders usually look for stable genotypes with improved performance in relation to a particular trait (Ramalho et al. 2012, Cruz et al. 2014). Studies on G x E interaction in cotton are scarce in Brazil, and in total, these studies evaluate fiber yield, not the length (Suinaga et al. 2006, Souza et al. 2006, Silva Filho et al. 2008, Farias et al. $2016 \mathrm{a}, \mathrm{b})$.

Thus, adaptability and phenotypic stability analysis are necessary, by which it is possible to identify genotypes with predictable behavior on the length of fibers, and which are responsive to environmental variations,
Crop Breeding and Applied Biotechnology 16: 340-347, 2016 Brazilian Society of Plant Breeding. Printed in Brazil http://dx.doi.org/10.1590/1984$70332016 v 16 n 4 n 50$ 
in specific or broad conditions (Farias et al. 2016b). Therefore, selection methods that incorporate stability and adaptability in a single statistics can be considered superior, when compared with those which use only yield as selection criteria (Resende 2007).

The analysis carried out by the method of mixed models was proposed to perennial crops, such as pine (Resende et al. 1996), and its application has been spread in the analysis of information on several crops, both perennial and annual. REML (Restricted Maximum Likelihood) estimates variance components required by the model, and BLUP (Best Linear Unbiased Prediction) estimates the genotypic value (Resende 2007).

The use of mixed models allows ranking the genotypes taking into consideration, simultaneously, their genetic values (estimated trait) and stability (Rosado et al. 2012). The lower the standard deviation of genotypic behavior across sites, the greater is the harmonic mean of their genotypic values (HMGV) across sites. Thus, selection by the greatest HMGV values implies simultaneously in the selection for the evaluated trait and stability. In terms of adaptability, a statistics used in the context of mixed models refers to the relative performance of genotypic values (RPGV) across the environments. In this case, the predicted genotypic values (or the original data) are expressed as a proportion of overall mean of each location, and then, the mean value of this proportion across sites is obtained (Carbonell et al. 2007, Resende 2007).

The simultaneous selection of cotton genotypes with greater length of fibers, stability and adaptability, under the approach of mixed models, can be accomplished by the method of the harmonic mean of the relative performance of genetic values (HMRPGV) predicted. Carbonell et al. (2007) report the main advantages of this method: to provide estimates of adaptability and genotypic stability, whose breeding values are penalized by instability; to generate results in their own magnitude or scale of the evaluated trait, facilitating the recommendation of genotypes; to analyze unbalanced and not orthogonal designs; to analyze heterogeneous variances; to allow errors correlated within sites.

Thus, HMGV, RPGV and HMRPGV have been used as measures for the interpretation of genotypic stability and adaptability of crops, such as common bean (Carbonell et al. 2007), sugarcane (Bastos et al. 2007), cashew (Maia et al. 2009), eucalyptus (Rosado et al. 2012), rice (Regitano Neto et al. 2013), and cowpea (Torres et al. 2015, Torres et al. 2016). However, they have not been used for breeding purposes in cotton. The aim of this study was to employ the mixed models methodology for simultaneous selection of cotton genotypes with greater length of fibers, adaptability and stability.

\section{MATERIAL AND METHODS}

It was evaluated lines derivative from cross between Guazuncho2 with Acala SJ4 of long fiber. Seeds were advanced from $\mathrm{F}_{2}$ to $\mathrm{F}_{4}$. The genealogical selection procedure was used from the $\mathrm{F}_{4}$ generation. In the latest generation, it was obtained $271 \mathrm{~F}_{4}$ plants, and of these, $51 \mathrm{~F}_{4: 5}$ plants were selected with length $\geq 31 \mathrm{~mm}$. Subsequently, in a greenhouse, it was selected $34 F_{5}: F_{6}$ lines with length $\geq 32 \mathrm{~mm}$, which were evaluated and analyzed by Carvalho et al. (2015b). In the remaining lines, it was selected only those with length $\geq 32 \mathrm{~mm}$. These lines were evaluated in three trials located in Apodi-RN (under irrigation), in 2013 and 2014, and in Santa Helena-GO (without irrigation), in 2013, in a randomized block design with two replications.

The plot consisted of two $5 \mathrm{~m}$ rows, spaced $0.80 \mathrm{~m}$, totaling 60 plants per row. Cultural practices were normal for cotton crop, with the use of herbicide for weed control. Pest control was carried out according to the integrated management of pests recommended for the crop in the region. Length of fibers was evaluated in samples with 20 bolls per plot, using the High volume instrument device (HVI) of the Fibers Laboratory of Embrapa Algodão.

To evaluate the effect of $\mathrm{G} \times \mathrm{E}$ interaction, it was used the statistical model 54 (Model = elites cotton genotypes, multiple locations, multiple observations per plot) of the Selegen-Reml/Blup software (Resende 2007). This model corresponds to $\mathrm{y}=\mathrm{Xb}+\mathrm{Zg}+\mathrm{Wc}+\mathrm{e}$, in which $\mathrm{y}, \mathrm{b}, \mathrm{g}, \mathrm{c}$, and e correspond respectively to the fixed effects of data vectors (blocks means by environments), genotype effects (random), effects of genotype x environment interaction (random), and random errors; and $\mathrm{X}, \mathrm{Z}$ and $\mathrm{W}=$ incidence matrices for $\mathrm{b}, \mathrm{g}$, and $\mathrm{c}$, respectively. The assumed distributions and mean structures $(S)$ and variance (Var) were: 


$$
\mathrm{S}\left[\begin{array}{l}
\mathrm{y} \\
\mathrm{g} \\
\mathrm{c} \\
\mathrm{e}
\end{array}\right]=\left[\begin{array}{c}
\mathrm{Xb} \\
0 \\
0 \\
0
\end{array}\right] ; \quad \operatorname{Var}\left[\begin{array}{l}
\mathrm{g} \\
\mathrm{c} \\
\mathrm{e}
\end{array}\right]=\left[\begin{array}{ccc}
\mathrm{I} \sigma_{\mathrm{g}}^{2} & 0 & 0 \\
0 & \mathrm{I} \sigma_{\mathrm{c}}^{2} & 0 \\
0 & 0 & \mathrm{I} \sigma_{\mathrm{g}}^{2}
\end{array}\right]
$$

The adjusted model was obtained from the mixed model equations: $\left[\begin{array}{ccc}X^{\prime} X & X^{\prime} Z & X^{\prime} W \\ Z^{\prime} X & Z^{\prime} Z+I \lambda_{1} & Z^{\prime} W \\ W^{\prime} X & W^{\prime} Z & W^{\prime} W+I \lambda_{2}\end{array}\right] \times\left[\begin{array}{c}\hat{b} \\ \hat{g} \\ \hat{c}\end{array}\right]=\left[\begin{array}{c}X^{\prime} y \\ Z^{\prime} y \\ W^{\prime} y\end{array}\right]$, in which $\lambda_{1}=\frac{\sigma_{\mathrm{g}}^{2}}{\sigma_{\mathrm{g}}^{2}}=\frac{1-\mathrm{h}_{\mathrm{g}}^{2}-\mathrm{c}^{2}}{\mathrm{~h}_{\mathrm{g}}^{2}} ; \lambda_{2}=\frac{\sigma_{\mathrm{g}}^{2}}{\sigma_{\mathrm{c}}^{2}}=\frac{1-\mathrm{h}_{\mathrm{g}}^{2}-\mathrm{c}^{2}}{\mathrm{c}_{\mathrm{g}}^{2}}$, in which: $\mathrm{h}_{\mathrm{g}}^{2}=\frac{\sigma_{\mathrm{g}}^{2}}{\sigma_{\mathrm{g}}^{2}+\sigma_{\mathrm{c}}^{2}+\sigma_{\mathrm{g}}^{2}}$ corresponds to broad-sense individual heritability in the block; $\mathrm{c}^{2}=\frac{\sigma_{\mathrm{c}}^{2}}{\sigma_{\mathrm{g}}^{2}+\sigma_{\mathrm{c}}^{2}+\sigma_{\mathrm{e}}^{2}}$ is the coefficient of determination of the effects of genotype $x$ environment interaction; $\hat{\sigma}_{g}^{2}$ is the genotypic variance; $\hat{\sigma}_{c}^{2}$ is the variance of genotype $x$ environment interaction; $\hat{\sigma}_{e}^{2}$ is the residual variance between plots; $r_{\mathrm{g} l o c}=\frac{\sigma_{c}^{2}}{\sigma_{g}^{2}+\sigma_{c}^{2}}=\frac{h_{g}^{2}}{h_{g}^{2}+c^{2}}$ is the genotypic correlation of genotypes across the environments.

Estimators of the variance components obtained by REML procedure via Expectation-Maximization algorithm (EM) are: $\hat{\sigma}_{\mathrm{e}}^{2}=\frac{\left\lfloor\mathrm{y}^{\prime} \mathrm{y}-\hat{\mathrm{b}}^{\prime} \mathrm{X}^{\prime} \mathrm{y}-\hat{\mathrm{g}}^{\prime} \mathrm{Z}^{\prime} \mathrm{y}-\hat{\mathrm{c}} \mathrm{W}^{\prime} \mathrm{y}\right\rfloor}{[\mathrm{N}-\mathrm{r}(\mathrm{x})]} ; \hat{\sigma}_{\mathrm{g}}^{2}=\frac{\left\lfloor\hat{\mathrm{g}}^{\prime} \hat{\mathrm{g}}+\hat{\sigma}_{\mathrm{e}}^{2} \mathrm{trC}^{22}\right\rfloor}{\mathrm{q}} ; \hat{\sigma}_{\mathrm{c}}^{2}=\frac{\left\lfloor\hat{\mathrm{c}}^{\prime} \mathrm{c}+\hat{\sigma}_{\mathrm{e}}^{2} \operatorname{trC}^{33}\right\rfloor}{\mathrm{s}}$, in which: $\mathrm{C}^{22}$ and $\mathrm{C}^{33}$ come from $\mathrm{C}^{-1}=\left[\begin{array}{lll}\mathrm{C}_{11} & \mathrm{C}_{12} & \mathrm{C}_{13} \\ \mathrm{C}_{21} & \mathrm{C}_{22} & \mathrm{C}_{23} \\ \mathrm{C}_{31} & \mathrm{C}_{32} & \mathrm{C}_{33}\end{array}\right]^{-1}=\left[\begin{array}{lll}\mathrm{C}^{11} & \mathrm{C}^{12} & \mathrm{C}^{13} \\ \mathrm{C}^{21} & \mathrm{C}^{22} & \mathrm{C}^{23} \\ \mathrm{C}^{31} & \mathrm{C}^{32} & \mathrm{C}^{33}\end{array}\right]$, in which $\mathrm{C}$ is the coefficient matrix of the mixed model equations; tr is the operator matrix trace; $r(x)$ is the rank of the matrix $X ; N, q, s$ are the total number of data, the number of genotypes, and the number of genotype $x$ environment combinations, respectively.

By using this model, it was obtained empirical BLUP predictors (eBLUP or REML/BLUP) of the genotypic values free of interaction, given by $\hat{\mu}+\hat{g}_{i}$, in which $\hat{\mu}$ is the mean of all environments, and $\hat{g}_{i}$ is the genotypic effect free of genotype $\mathrm{x}$ environment interaction. For each environment $\mathrm{j}$, genotypic values $(\mathrm{Vg})$ are predicted by $\hat{\mu}+\hat{g}_{i}+(\hat{g} e)_{i j}$, in which $\hat{\mu}_{j}$ is the mean of the environment $\mathrm{j} ; \hat{g}_{i}$ is the genotypic effect of genotype $\mathrm{i}$ on the environment $\mathrm{j}$; and $(\hat{g} e)_{i j}$ is the effect of genotype $x$ environment interaction in relation to the genotype $i$.

Prediction of genotypic values that capitalize the mean interaction in different environments is given by $\hat{\mu}_{j}+\hat{g}_{i}+\hat{g} \mathrm{e}_{m^{\prime}}$, and is calculated by: $\hat{\mu}+\frac{\left(\frac{\hat{\sigma}_{g}^{2}+\hat{\sigma}_{c}^{2}}{\mathrm{n}}\right)}{\hat{\sigma}_{g}^{2}} \hat{\mathrm{g}}_{i}$, in which $\hat{\mu}$ is the overall mean of all environments; $\mathrm{n}$ is the number of environments; and $\hat{g}_{i}$ is the genotypic effect of the genotype $\mathrm{i}$.

Harmonic mean values of the genotypic values (HMGV) for stability evaluation were obtained by the equation: $\mathrm{HMGH}_{i}=\frac{\mathrm{n}}{\sum_{\mathrm{j}=1}^{n} \frac{1}{\mathrm{Vg}_{\mathrm{ij}}}}$, in which: $\mathrm{n}$ is the number of environments $(\mathrm{n}=3)$ in which the genotype i was evaluated; $V g_{i j}$ is the genotypic value of the genotype i on the environment $j$, expressed by the ratio of the mean in this environment. The values of the relative performance of the genotypic values (RPGV) for adaptability were obtained according to 
the expression: $R P G V_{i}=\frac{1}{n} \frac{\sum_{j=1}^{n} V g_{i j}}{M_{j}}$, in which $M_{j}$ is the mean of the fiber length in the environment $j$. Joint selection simultaneously considering seed length of fibers, stability and adaptability is given by the statistical harmonic mean of the relative performance of genotypic values predicted (HMRPGV): HMRPGV $i_{i}=\frac{n}{\sum_{j=1}^{n} \frac{1}{\text { RRVg }_{i j}}}$ (Resende 2007). Thus, the genotypes with greater HMRPGV are those that simultaneously present greater length of fibers, adaptability and genotypic stability in the environments evaluated in this study.

\section{RESULTS AND DISCUSSION}

Coefficient of experimental variation ( $\mathrm{CV}_{\mathrm{e}}$ ) was $3.20 \%$ (Table 1), which is lower than those of other studies carried out with the cotton crop (Carvalho et al. 2015b, Carvalho et al. 2015c, Hoogerheide et al. 2007), which indicates excellent experimental precision. In another interpretation, the value obtained for $\mathrm{CV}_{\mathrm{g}}(4.76 \%)$ indicates that a considerable fraction of MSgenotypes was extracted from MStotal. Joint evaluation of $\mathrm{CV}_{\mathrm{g}}$ and $\mathrm{CV}_{\mathrm{e}}$ is reflected in the statistics $\hat{r}_{g \hat{g}}$ (Resende and Duarte 2007). The accuracy obtained (96\%) shows excellent experimental quality, and thus safety and credibility in the selection of superior genotypes for the trait length of fibers.

Heritability of the genotypes means $\left(\hat{h}_{m g}^{2}\right)$ is estimated when using means of the blocks as evaluation and/or selection criteria (Resende 2007). Thus, in the face of the values obtained (0.91), there is reliability in the selection of elite cotton genotypes, based on the predicted genotypic values. In the estimate of the broad-sense individual heritability $\left(\hat{h}_{g}^{2}\right)$, the total genetic dispersion is considered, which is relevant since in this research it was sought to explore all the genetic variance between cotton progenies. The variance of the genotypic effects $\left(\hat{\sigma}_{g}^{2}\right)$ presented magnitude highly greater than the variance of the effects of $\mathrm{G} \times \mathrm{E}$ interaction $\left(\hat{\sigma}_{c}^{2}\right)$, constituting $66 \%$ of the total phenotypic variability, represented by the heritability of individual plots $\left(\hat{h}_{g}^{2}\right)$. Results with similar magnitude were observed by Maia et al. (2009), Rosado et al. (2012) and Laviola et al. (2012), when estimating genetic parameters via REML/BLUP in cashew clones, eucalyptus and jatropha, respectively.

Due to the greater or lesser degree of adaptability/ genetic stability of individuals, the variance of the $\mathrm{G} \times \mathrm{E}$ interaction $\left(\hat{\sigma}_{c}^{2}\right)$ can inflate the phenotypic expression of a trait (Bastos et al. 2007). This measure quantifies the fraction of the total variation due to the $G \times E$ interaction. Small magnitude estimates of $\hat{\sigma}_{c}^{2}$ indicates that the $\mathrm{G} \times \mathrm{E}$ interaction little influences on phenotypic value (Maia et al. 2009). In this context, a genotype with greater length of fibers in an environment tends to maintain the same level in different environments, since this genotype responds favorably to environmental influences (high correlation between genotypic values across the sites), in addition to have high predictability in the face of environmental changes. Estimates of $\hat{\sigma}_{c}^{2}$ can be considered low, corresponding to $3.61 \%$ of the total phenotypic variability, which favors the achievement of extremely high phenotypic correlation $\left(\hat{r}_{\text {gloc }}=0.95\right)$ among the environments.

Phenotypic value corresponds to the values obtained in the field evaluations, which are influenced by genotypic effect and effect of $G \times E$ interaction. In the latter, the sum of the genotypic variance, of the residual variance between plots, and of the variance of the $\mathrm{G} \times \mathrm{E}$ interaction results in

Table 1. Estimates of variance components (individual REML) for length of fiber in 36 cotton genotypes evaluated in three environments

\begin{tabular}{lc}
\hline Parameter & Estimate \\
\hline$\hat{\sigma}_{g}^{2}$ & $2.02 \pm 0.12$ \\
$\hat{\sigma}_{c}^{2}$ & $0.11 \pm 0.01$ \\
$\hat{\sigma}_{e}^{2}$ & $0.91 \pm 0.26$ \\
$\hat{\sigma}_{p}^{2}$ & $3.04 \pm 0.75$ \\
$\hat{h}_{g}^{2}$ & $0.66 \pm 0.16$ \\
$\hat{h}_{m g}^{2}$ & $0.91 \pm 0.18$ \\
$\hat{r}_{g \hat{g}}$ & $0.96 \pm 0.09$ \\
$c^{2}$ & $0.04 \pm 0.01$ \\
$\hat{r}_{\mathrm{gloc}}$ & $0.95 \pm 0.07$ \\
$\mathrm{CV}_{\mathrm{g}}(\%)$ & $4.76 \pm 0.27$ \\
$\mathrm{CV}_{\mathrm{e}}(\%)$ & $0.91 \pm 0.40$ \\
$\mu(\mathrm{mm})$ & $29.81 \pm 1.26$ \\
\hline
\end{tabular}

$\hat{\sigma}_{g}^{2}$ : genotypic variance; $\hat{\sigma}_{c}^{2}$ : variance of genotype x environment interaction; $\hat{\sigma}_{a}^{2}$ : residual variance between plots; $\hat{\sigma}_{n}^{2}$ : individual phenotypic variance; $\hat{h}_{g}^{2}$ : broadsense individual heritability; $\hat{h}_{m q}^{2}$ : mean of genotype heritability; $\hat{r}_{q g}:$ accuracy in the selection of genotypes; $c^{2}$ : coefficient of determination of effects of the genotype $x$ environment interaction; $\hat{r}_{\text {gloc }}$ : genotypic correlation across the environments; $\mathrm{CV}_{g}$ : coefficient of genetic variation; $\mathrm{CV}_{\mathrm{e}}$ : coefficient of experimental variation; $\mu$ : overall mean. 


\section{LP Carvalho et al.}

individual phenotypic variance $\left(\hat{\sigma}_{f}^{2}\right)$. Although the residual dispersion between plots $\left(\hat{\sigma}_{e}^{2}\right)$ represents $30.13 \%$ of this value, significant genetic progress was achieved. Results in similar magnitude were observed by Maia et al. (2009), Rosado et al. (2012), in which it was evaluated the effects of $\mathrm{G} x \mathrm{E}$ interaction on cashew and eucalyptus clones, respectively, via mixed models, it was found that the residual variance between plots represented $66.58 \%$ of the individual phenotypic variance (the two works had the same ratio between the variances).

The mean genotypic correlation of the genetic material performance across the environment $\left(\hat{r}_{\text {gloc }}\right)$ indicates the ranking reliability of the best genotypes in the tested environments. In general, small changes were observed in the ranking of genotypes, due to the high magnitude of $\hat{r}_{\text {gloc }}(0.95)$, and due to the high $\hat{r}_{g \hat{g}}(0.96)$. This indicates the occurrence of simple fraction of $\mathrm{G} \times \mathrm{E}$ interaction, favoring the selection of genotypes with broader adaptation.

The genotypes CNPA 2012-55, CNPA 2012-58, CNPA 2012-62 and CNPA 2012-64 showed the best gain estimates with

Table 2. Estimates of genotypic values for length of fiber in 36 cotton genotypes evaluated in three environments and for average environment

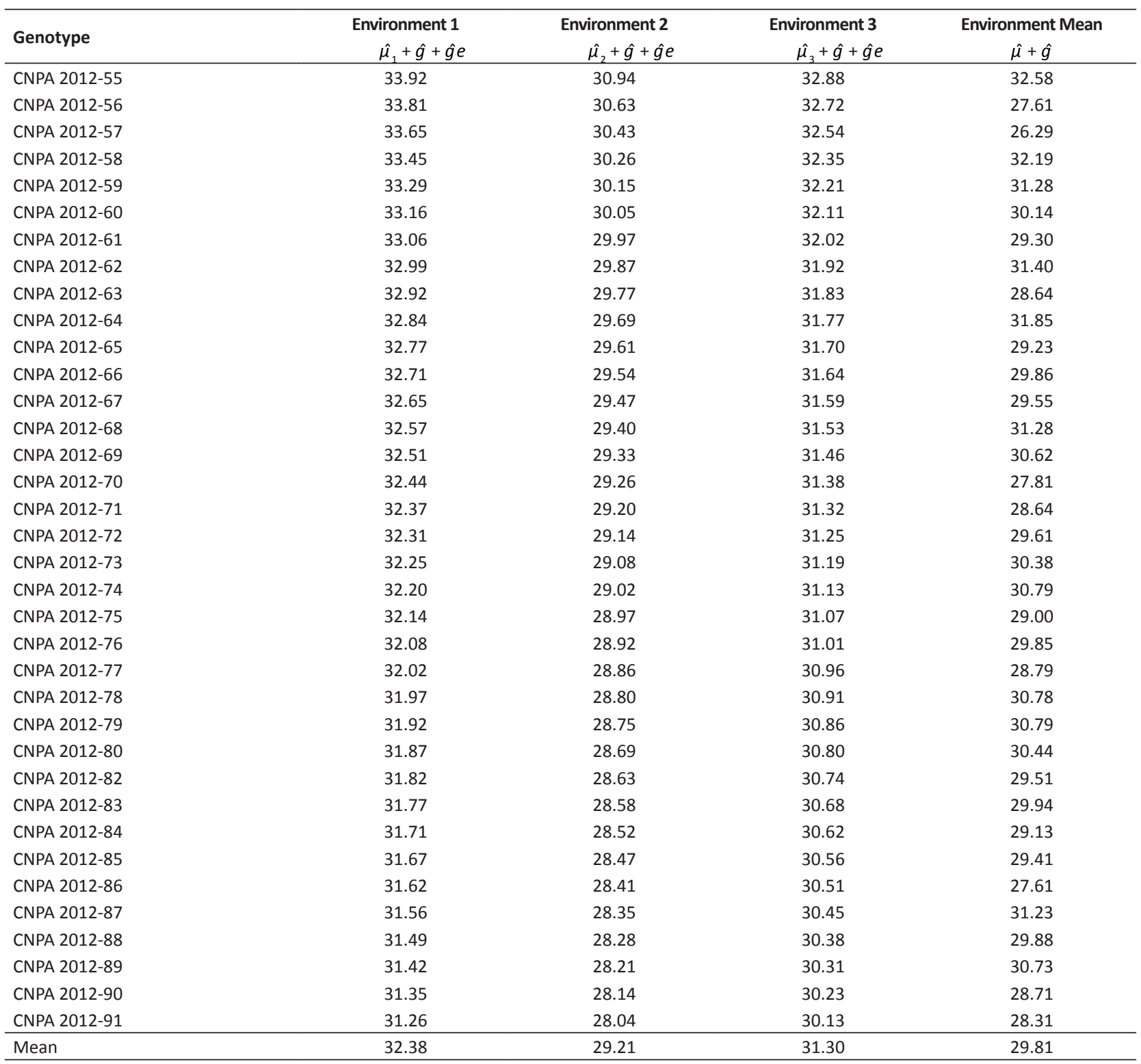


Table 3. Stability of genetic values (HMGV), adaptability of genetic values (RPGV and RPGV $\mu$ ), stability and adaptability of genetic values (HMRPGV and HMRPGV $\mu$ ) for length of fibers $(\mathrm{mm})$ of 36 cotton genotypes predicted by BLUP analysis

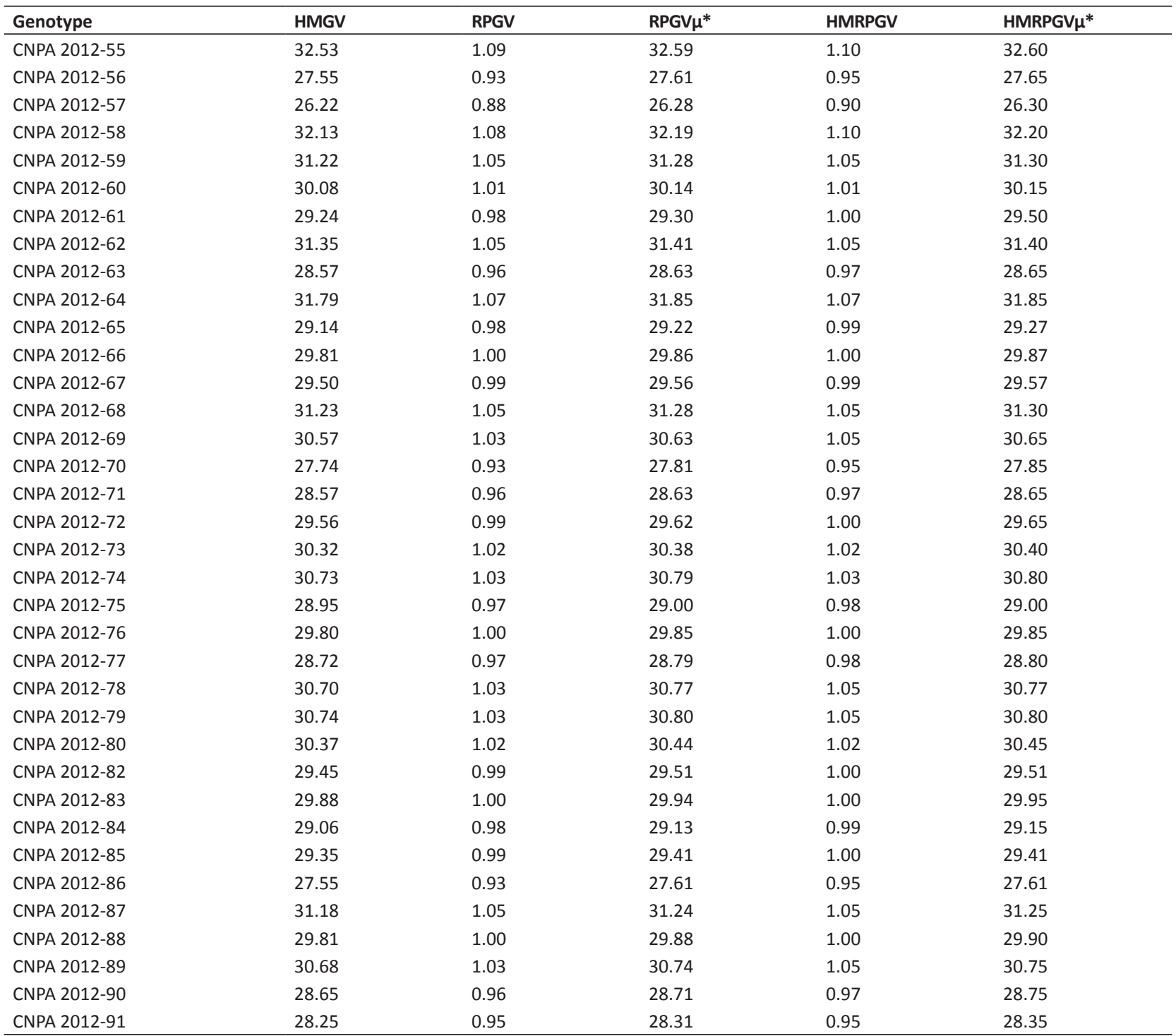

* values of RPGV $\mu$ and HMRPGV $\mu$ were obtained by multiplying the genotypic value of the length of fibers from genotype i with the statistics RPGV and HMRPGV, respectively.

selection in all environments (Table 2). The genetic gains obtained with the selection of the genotypes were respectively: $19.29,17.96,15.78$ and $14.98 \%$. These genotypic values can also be considered for recommendation of these genotypes, which were selected in other environments with standard $\mathrm{G} \times \mathrm{E}$ interaction similar to those observed in this study. According to Maia et al. (2009), this is because the method of mixed models penalizes predicted genotypic values. Thus, the same behavior of the genetic means $(\hat{\mu}+\hat{g})$ of the length of fiber is expected, when the aforementioned genotypes are subjected to environments with characteristics similar to those of this study.

Table 2 shows that the genotypic value for the mean of environments $(\hat{\mu}+\hat{g})$ generated results similar to the methods in which adaptability (RPGV), adaptability and stability (HMRPGV) are simultaneously capitalized (Table 3). According to Maia et al. (2009), the capitalization of the $\mathrm{G} \times \mathrm{E}$ interaction depends on the selection of genotypes for greater adaptability and stability to the evaluated environments. This criterion is repeated in the genotypes CNPA 2012-55, CNPA 2012-58, CNPA 2012-62 and CNPA 2012-64, selected by the genetic means free of interaction $(\hat{\mu}+\hat{g})$. This fact indicates that these 


\section{LP Carvalho et al.}

genotypes presented adaptability and genotypic stability between the three environments analyzed, in addition to having high length of fibers, i.e., the maintenance of this trait across the different environments. These results corroborate those obtained by Maia et al. (2009), Regitano Neto et al. (2013) and Torres et al. (2016), who verified the maintenance of the ranking of cashew clones, rice genotypes and cowpea, respectively, by genotypic value of methods for the mean of years $(\hat{\mu}+\hat{g})$, HMGV, RPGV and HMRPGV, attributing these results to genotypic correlation across sites $\left(\hat{r}_{\text {gloc }}\right)$, which was positive and of similar magnitude to those of study.

\section{REFERENCES}

Bastos IT, Barbosa MHP, Resende MDV, Peternelii LA, Silveira LCI, Donda LR, Fortunato AA, Costa PMA and Figueiredo ICR (2007) Avaliação da interação genótipo $x$ ambiente em cana-de-açúcar via modelos mistos. Pesquisa Agropecuária Tropical 37: 195-203.

Carbonell SAM, Chioratto AF, Resende MDV, Dias LAS, Beraldo ALA and Perina EF (2007) Estabilidade de cultivares e linhagens de feijoeiro em diferentes ambientes no Estado de São Paulo. Bragantia 66: 193-201.

Carvalho LP, Farias FJC and Rodrigues JIS (2015a) Selection for increased fiber length in cotton progenies from Acala and Non-Acala types. Crop Science 55: 1-7.

Carvalho LP, Salgado CC, Farias FJC and Carneiro VQ (2015b) Estabilidade e adaptabilidade de genótipos de algodão de fibra colorida quanto aos caracteres de fibra. Ciência Rural 45: 598-605.

Carvalho LP, Farias FJC, Morelo CL, Rodrigues JIS and Teodoro PE (2015c) Agronomic and technical fibers traits in elite genotypes of cotton herbaceous. African Journal of Agricultural Research 10: 4882-4887.

Carvalho LP, Farias FJC, Morelo CL and Teodoro PE (2016) Uso da metodologia REML/BLUP para seleção de genótipos de algodoeiro com maior adaptabilidade e estabilidade produtiva. Bragantia 75: 314-321.

Cruz CD, Carneiro PCS and Regazzi AJ (2014) Modelos biométricos aplicados ao melhoramento genético. $3^{\text {rd }}$ edn, Editora UFV, Viçosa, $668 p$.

Farias FJC, Carvalho LP, Silva Filho JL and Teodoro PE (2016a) Biplot analysis of phenotypic stability in upland cotton genotypes in Mato Grosso. Genetics and Molecular Research 15: 1-8.

Farias FJC, Carvalho LP, Silva Filho JL and Teodoro PE (2016b) Usefulness of the HMRPGV method for simultaneous selection of upland cotton genotypes with greater fiber length and high yield stability. Genetics and Molecular Research 15: 1-8.

Hoogerheide ESS, Vencovsky R, Farias FJC, Freire EC and Arantes EM (2007) Correlações e análise de trilha de caracteres tecnológicos e produtividade de fibra de algodão. Pesquisa Agropecuaria Brasileira 42: 1401-1405.

Laviola BG, Alves AA, Gurgel FD, Rosado TB, Rocha RB and Albrecht JC (2012) Estimates of genetic parameters for physic nut traits based in the germplasm two years evaluation. Ciência Rural 42: 429-435.

Maia MCC, Resende MDV, Paiva JR, Cavalcanti JJV and Barros LM (2009) Seleção simultânea para produção, adaptabilidade e estabilidade genotípicas em clones de cajueiro, via modelos misto. Pesquisa
Agropecuária Tropical 39: 43-50.

Menezes IPP, Hoffmann LV and Barroso PAV (2015) Genetic characterization of cotton landraces found in the Paraíba and Rio Grande do Norte states. Crop Breeding and Applied Biotechnology 15: 26-32.

Morello CL, Suassuna ND, Barroso PAV, Silva Filho JL, Ferreira ACB, Lamas FL, Pedrosa MB, Chitarra LG, Ribeiro JL, Godinho VPC and Lanza MA (2015) BRS 369RF and BRS 370RF: Glyphosate tolerant, high-yielding upland cotton cultivars for central Brazilian savanna. Crop Breeding and Applied Biotechnology 15: 290-294.

Ramalho MAP, Abreu AFB, Santos JB and Nunes JAR (2012) Aplicações da genética quantitativa no melhoramento de plantas autógamas. UFLA, Lavras, 328p.

Regitano Neto A, Ramos Júnior EA, Gallo PB, Freitas JG and Azzini LE (2013) Comportamento de genótipos de arroz de terras altas no estado de São Paulo. Revista Ciência Agronômica 44: 512-519.

Resende MDV (2007) SELEGEN-REML/BLUP: sistema estatístico e seleção genética computadorizada via modelos lineares mistos. Embrapa Florestas, Colombo, 359p.

Resende MDV, Prates DF, Yamada CK and Jesus A (1996) Estimação de componentes de variância e predição de valores genéticos pelo método da máxima verossimilhança restrita (REML) e melhor predição linear não viciada (BLUP) em pinus. Boletim de Pesquisa Florestal 32-33: 23-42.

Resende MDV and Duarte JB (2007) Precisão e controle de qualidade em experimentos de avaliação de cultivares. Pesquisa Agropecuária Tropical 37: 182-194.

Rosado AM, Rosado TB, Alves AA, Laviola BG and Bhering LL (2012) Seleção simultânea de clones de eucalipto de acordo com produtividade, estabilidade e adaptabilidade. Pesquisa Agropecuária Brasileira 47: 964-971.

Silva Filho J.L, Morello CL, Farias FJC, Lamas FM, Pedrosa MB and Ribeiro JL (2008) Comparação de métodos para avaliar a adaptabilidade e estabilidade produtiva em algodoeiro. Pesquisa Agropecuária Brasileira 43: 349-355.

Smith CW, Hague S, Hequet E, Thaxton S and Brown N (2008) Development of extra-long staple upland cotton. Crop Science 48: 1823-1832.

Souza AA, Freire EC, Bruno RLA, Carvalho LP, Silva Filho LP and Pereira WE (2006) Estabilidade e adaptabilidade do algodoeiro herbáceo no cerrado do Mato Grosso e Mato Grosso do Sul. Pesquisa Agropecuária Brasileira 41: 1125-1131.

Suinaga FA, Bastos CS and Rangel LEP (2006) Phenotipic adaptability and 
stability of cotton cultivars in Mato Grosso State, Brazil. Pesquisa Agropecuária Tropical 36: 145-150.

Torres FE, Teodoro PE, Rodrigues EV, Santos A, Corrêa AM and Ceccon $\mathrm{G}$ (2016) Simultaneous selection for cowpea (Vigna unguiculata L.) genotypes with adaptability and yield stability using mixed models.
Genetics and Molecular Research 15: 1-11.

Torres FE, Teodoro PE, Sagrilo E, Corrêa AM and Ceccon G (2015) Interação genótipo $x$ ambiente em genótipos de feijão-caupi semiprostrado via modelos mistos. Bragantia 74: 255-260. 